\title{
Computer Programming Teachers' Challenges for Promoting Students Regulation on Flipped Learning Activities during COVID-19
}

Desafios dos professores de programação de computadores para promover a regulação dos alunos em atividades de aprendizagem invertida durante o COVID-19

Desafios de los profesores de programación informática para promover la regulación de los estudiantes en las actividades de aprendizaje invertida durante COVID-19

\author{
ANDERSON CAVALCANTE GONÇALVES (iDa \\ DELLER JAMES FERREIRA (Db \\ Valdemar Vicente Graciano Neto (Did
}

\begin{abstract}
The challenges for computer programming teachers are great, it is difficult to teach concepts and structures inherent in the programming language to students in introductory courses in the field of computer science. The coronavirus pandemic, COVID-19, intensified these difficulties as the entire teaching and learning process migrated to online platforms. The research aims to provide evidence regarding the

\footnotetext{
a Universidade Federal de Goiás; Universidade Estadual de Goiás, Goiânia, GO, Brasil. Mestre em Ciência da Computação, e-mail: anderson.goncalves@ueg.br

b Universidade Federal de Goiás, Goiânia, GO, Brasil. Doutora em Educação, e-mail: deller@ufg.br

c Universidade Federal de Goiás, Goiânia, GO, Brasil. Doutor em Ciências da Computação e Matemática Computacional e em Ciências e Tecnologia da Informação, e-mail: valdemarneto@ufg.br
} 
difficulties that computer science teachers are having to implement inverted classes. The analysis involves the knowledge of teachers' perceptions of collaborative teaching methods of problem solving, and with regulatory strategies to motivate students and promote reflections on their learning. The results indicate that teachers have had significant difficulties in understanding the use of active methodologies, also in understanding the learning students' profiles and how they can prepare, plan, implement and favor learning.

Keywords: Computer Programming. Challenges. Regulation. Flipped Learning. COVID-19.

\section{Resumo}

Os desafios para professores de programação de computadores são grandes; é difícil ensinar conceitos e estruturas inerentes à linguagem de programação aos alunos em cursos introdutórios na área de informática. A pandemia de coronavírus, COVID-19, intensificou essas dificuldades à medida que todo o processo de ensino e aprendizagem migrou para as plataformas online. A pesquisa visa fornecer evidências sobre as dificuldades que os professores de informática estão tendo para implementar aulas invertidas. A análise envolve o conhecimento das percepções dos professores sobre os métodos de ensino colaborativos de resolução de problemas e com estratégias regulatórias para motivar os alunos e promover reflexões sobre a sua aprendizagem. Os resultados indicam que os professores apresentam dificuldades significativas na compreensão do uso das metodologias ativas, na compreensão do perfil dos alunos aprendizes e na forma como eles podem preparar, planejar, implementar e favorecer a aprendizagem.

Palavras-chave: Programação de computador. Desafios. Regulação. Aprendizagem Invertida. COVID-19.

\section{Resumen}

Los desafíos para los profesores de programación informática son grandes, es difícil enseñar conceptos y estructuras inherentes al lenguaje de programación a los estudiantes en cursos introductorios en el campo de la informática. La pandemia de coronavirus, COVID-19, intensificó estas dificultades a medida que todo el proceso de enseñanza y aprendizaje migró a las plataformas en línea. La investigación tiene como objetivo aportar evidencias sobre las dificultades que están teniendo los profesores de informática para implementar clases invertidas. El análisis involucra el conocimiento de las percepciones de los docentes sobre los métodos de enseñanza colaborativa de resolución de problemas, y con estrategias regulatorias para motivar a los estudiantes y promover reflexiones sobre su aprendizaje. Los resultados indican que los docentes han tenido importantes dificultades para comprender el uso de metodologías activas, 
también para comprender los perfiles de los estudiantes en aprendizaje y cómo pueden preparar, planificar, implementar y favorecer el aprendizaje.

Palabras clave: Programación de computadoras. Desafíos. Regulación. Aprendizaje invertido. COVID-19.

\section{Introduction}

The traditional teaching model involves a pedagogical structure where the teacher is the center of learning, acting as Knowledge holder (AWIDI; PAYNTER, 2019; BAARS; WIJNIA, 2018). In this model the construction of the Knowledge is limited because students act less actively in learning, since basically the interpretive process is activated (FIDALGO-BLANCO et al., 2017). In addition, although there is usually a time for interaction, some students may feel intimidated and discouraged from interacting (ALHAZBI, 2017).

Students' interactions can be even more essential when it comes to distance learning, in which students are focused on interacting on online teaching platforms (SHIH; SHENG-HUI, 2020). Online education, normally used as an auxiliary strategy to classroom teaching, became a predominant alternative to teaching at all levels during the COVID-19 pandemic (BAO, 2020).

During the COVID-19 pandemic, academics around the world had to change their practices immediately and migrate urgently to fully online education programs (NERANTZI, 2020). Faced with the new coronavirus pandemic, with numerous blockages around the world and with an uncertain future for education, institutions and educators around the world had to devise new strategies to make teaching viable and safe (LI; LALANI, 2020).

It is a challenge for teachers to learn and teach simultaneously through online platforms that allow interaction between teachers and students in order to share knowledge (NERANTZI, 2020).

During COVID-19's global pandemic situation, teacher-centered learning may not be sufficient to help students tackle complex problems (ANNAN; ONODIPE; STEPHENSON, 2019). An alternative that can be effective involves the use of active learning methodologies, such as flipped learning. 
In view of the countless challenges that teachers and students have to face in order to develop an online teaching strategy that helps to promote learning, flipped learning is presented as a potential solution (KHAN; ABDOU, 2021). Flipped learning changes the pedagogical didactic structure of the classes, helping to foster learning before, during and after the classroom. By building knowledge before class, students can engage in problem solving during class (BERGMANN; SAMS, 2012) and engage in after-class reflection processes that help develop learning (CHEN; HWANG; CHANG, 2019).

In the flipped classroom, the teacher acts as a learning mediator, ceasing to be the center and sole holder of knowledge, in order to support students in activities before classes and in group activities (HIRSTO; VAISAANEN; ARFFMAN, 2019), helping to foster the exploration of opportunities from different perspectives.

Although from theoretical perspectives it seems simple to implement the flipped classroom, it involves several complex factors that are decisive for the effectiveness of the method. It is a strategy that requires thorough teacher preparation and facilitating the regulation of activities, before, during and after classes $(\mathrm{KOH}$, 2019; BLAU; SHAMIR-INBAL, 2017; ZAINUDDIN et al., 2019). Before the classroom, students must effectively engage in the content proposed by the teacher, which requires motivation and engagement, during class they need to engage in fruitful discussions that permeate group collaborations (ZAINUDDIN et al., 2019) and after the classroom needs to emerge in reflective processes that contribute to learning (CHEN; HWANG; CHANG, 2019).

In addition, the flipped classroom method does not provide concrete design principles to assist the teacher in planning, creating and promoting the regulation of activities. So far, this type of detailed structure is unfortunately missing from the literature on flipped learning (BOELENS; DE WEVER; VOET, 2017). Consequently, researchers and professionals are still struggling with the implementation of the flipped classroom (ZHENG et al., 2019; OKMEN; KILIC, 2020).

The teacher to work in the flipped classroom needs to acquire or already have a background of regulatory processes coming from other areas of education, such as collaborative learning, adapting his knowledge to this context, which is not trivial. 
Several authors (RASHEED et al., 2020; AKÇAYIR; AKÇAYIR, 2018; MAYCOCK; LAMBERT; BANE, 2018; BOELENS; DE WEVER; VOET, 2017; HALVERSON, 2016) point out a multitude of strategies aimed at facilitating the regulation of students in the flipped classroom, such as: orientation, planning, monitoring, adjustment and evaluation of activities, motivation and help to the student regarding the emotional aspect. The teacher needs, for example: to prepare and design the learning process by examining the characteristics of the learning task and determining learning goals, prior knowledge or time constraints; verify that the learning process advances according to the plan; adjust the initial learning plan based on the results of the monitoring activity; assess the extent to which the final learning outcome is in line with the initial plan; motivating students' willingness to learn and forming expectations about the course and the results of the learning process; direct attention to aspects relevant to the task, rather than distraction, thoughts irrelevant to the task, and perform thinking activities that require mental effort; motivate the student to judge himself; assign subjective values to learning tasks, encouraging a willingness to invest energy; and help the student to deal with yours emotions in a productive way (AKÇAYIR; AKÇAYIR, 2018; RASHEED et al., 2020).

Thus, we have that it is intimidating and challenging for the teacher to engage in a pedagogical strategy that requires a significant change in the teaching and learning process. The teacher's facilitation of self-regulation and co-regulation among students, which presupposes mastery over technologies and learning methodologies arising from pedagogies, which go beyond the sphere of the flipped classroom, is fundamental for the success of flipped learning that is a highly complex and laborious process (LA MARCA; LONGO, 2017; DOO et al., 2020).

The implementation of flipped learning has a high level of complexity when it comes to teaching programming (VOJINOVIC et al., 2020). Programming teaching involves notions of logic, structured in a language for the design of algorithms that solve specific problems. With flipped learning, teaching can become more interactive, which can help achieve better learning outcomes. However, in the flipped classroom, teaching programming is a task that requires great dedication from teachers and students (DURAK, 2019; KARACA; OCAK, 2017). 
In this context, the objective of this research is to provide evidence of the extent to which computer science teachers, who teach introductory computer programming, are prepared to face the challenges of using flipped learning in the context of computer programming. It will be investigated whether teachers are familiar with collaborative teaching methods of problem solving, and with regulatory strategies to motivate students and promote reflections on their learning.

\section{Related Works}

In the literature, we observe works that involve teaching strategies for regulation in different ways. The research by Hung et al. (2020) presents a study, using a hybrid learning approach, which involves a mix of online teaching with classroom teaching, for teaching programming. The context of the study involves an approach in which the student is the center of learning, in which the teacher regulates activities by providing the means for students to learn at any time and place.

The proposal integrates educational data mining with the aim of investigating and exploring student behavior in hybrid learning courses. The models adopted aim to involve flipped learning, applied to a Python programming course. The score obtained by the students shows potential in the approach. Strategies such as a map to define learning patterns were used, as an interactive group, stable learning group, positive teaching group and negative teaching group. The work presents satisfactory results for flipped learning. The main teaching approaches offer teachers the possibility to mediate group activities based on behavior analysis. The results were successful and improvements in student learning were observed.

Yamashita and Yasueda's (2017) proposal presents a study that focuses on the idea of students getting involved in communities mediated by the teacher, both in the classroom and before the classroom, using collaborative software. The context of the study involves project-based learning in order to plan events involving students. The proposal integrates the flipped learning model and active learning methodologies. The methodology adopted involves obtaining it through questionnaires proposed and collected in the communities before and during the classroom to analyze qualitative 
data. The results were successful, and an innovative potential was observed in the students' learning.

Durak's (2019) proposal presents a study that involves the basic concepts of programming and its fundamentals. The proposal integrates training to learn programming, which is considered a challenging task for students and a complex process for teachers to teach concepts that require student dedication. The models adopted address a wide range of correlated methods such as problem-solving skills and flipped learning that involves levels of learning readiness. The work was applied to a class in the Computer Science course. For the execution of the study, a relational model screening, a form, a performance test and three different levels of data collection were designed. To obtain the results, a multivariate statistical analysis technique was used to analyze the results and different variables of the class involved in the programming study. The results indicate that flipped learning contributed significantly to the cognitive flexibility that contributed to the learning and development of programming students.

The proposal by Peethambaran, Renumol and Murthy (2019) presents a study related to how to help students develop the skills necessary to learn programming, which is a major concern for teachers in the field of computing. The context of the study shows that programming involves higher thinking skills and that teachers can use many teaching strategies to help students develop higher-order thinking skills. The models adopted involve the flipped classroom as an innovative method to develop such skills. The work presents the strategy of implementing flipped learning in teaching Java programming to students with low performance and using the traditional method of teaching with students who obtain high performance. The objective is to examine the results of students with low performance in programming, but involved in flipped learning, with students with high performance involved in traditional teaching. The aim is to improve student performance in the Java programming course. The results, which involved a flipped classroom, indispensable that the students with low performance had an equal performance to the students with better performance in the traditional classroom. The involvement of the teacher in group interactions during the pre-class moment and in defined class students with 
low performance to improve results, reaching students with high performance in the traditional model of teaching.

Although there are many works that address challenges and approaches for facilitating students flipped learning applied to the area of computer programming, and that numerous works address students as the center of learning (LOFTSSON; MATTHÍASDÓTTIR, 2019; VOJINOVIC et al., 2020), there is no specific work in the literature that involves an empirical study to assess how much computer science teachers, involved in programming disciplines, are prepared or not to promote regulation, which is essential for the success of flipped learning.

The teacher must be able to prepare, design and specific classes for the preparation of each task, to verify if the learning goals will be achieved. You also need to interact with students to adjust time, avoid procrastination, motivate students, and help create learning-related expectations in order to assist students during flipped learning so that all phases are performed successfully.

\section{Methodology}

A mixed, quantitative and qualitative research methodology was adopted to help explore and analyze the interpretation of the results obtained in the research (CRESWELL, 2015) carried out by means of a structured questionnaire to investigate questions and challenges present to facilitate the documentation of the regulations of the companies. flipped learning activities during a Covid-19 pandemic.

The study is structurally based on a qualitative approach related to the investigation of the challenges of teaching promotion of learning in flipped learning during a pandemic.

\section{Participants}

Fifty-two professors from several universities in Brazil participated in the study. The investigated teachers are involved in remote education, in which all content is taught at a distance using specialized resources such as teaching and video conferencing platforms. 
The majority of those involved in the survey are male, 54.9 percent. A significant number of investigated professors (33.3 percent) have experience of 20 years or more, and 54.9 percent of those investigated are Ph.D professors.

\section{Instruments}

Qualitative data was collected to analyze and identify the challenges perceived by teachers during teaching in the pandemic by Covid-19 and the preparation of teachers to regulate activities related to flipped learning during the pandemic by COVID-19. A questionnaire containing closed and open questions was administered to all participating teachers, who were invited to provide answers on the challenges and teaching methods used in remote education and flipped learning. The questions that make up the proposed questionnaire are shown below, so that teachers could report the possible success, difficulties, anxieties and doubts about the application of classes via remote education during the Covid-19 pandemic, especially with regard to their ability to apply strategies that allow the regulation of the student. In summary, the questionnaire was applied to teachers to investigate the experience related to teaching and remote learning.

The questionnaire was designed according to the guidelines of Mathers, Fox and Hunn (2009). The questionnaire can be answered independently by the participants and does not have characteristic filters; it must be well defined and have simple instructions. These are important guidelines and recommendations for the construction of the questionnaire:

- The title - All questionnaires require a title. It needs to be short, simple, attractive and inviting, not the full academic title of the study.

- The identifier - Names and addresses must not appear on the questionnaire itself.

- Instructions - It is essential to include instructions in the questionnaire.

- Closed questions - A closed question is one in which the possible answers are defined in advance and, therefore, the respondent is limited to one of the pre-coded answers provided. 
- Open questions - An open question does not restrict possible answers. For example, "Do you use any teaching method to promote student participation in class? Which one?" (MATHERS; FOX; HUNN, 2009).

The questionnaire was based on guidelines that include aspects related to the educational experience to promote the regulation of learning in introductory computer courses during the Covid-19 pandemic. The guidelines involve:

1. Why, related to content, in terms of understanding the reason for using learning methodologies.

2. Who, related to the current status and needs, in terms of understanding the learning profile of students, the current status of the teaching and learning process and adaptations that involve the analysis of students' needs.

3. How, related to learning, design and implementation, related to how to prepare, plan, implement and favor learning with the use of active learning methodologies (CHOI; TINIO, 2020).

\section{Data Collection and Analysis}

Data collection and analysis was carried out to provide evidence about the teacher's knowledge and preparation for the use of active learning methodologies to regulate flipped learning activities during the Covid-19 pandemic.

Crucial aspects for teaching and learning are investigated, such as the experience of using teaching methods that support learning, methods that encourage student collaboration, problem solving, involving essential factors so that the teacher can properly mediate classes.

The study focuses on the analysis of data collected from university professors who are involved in classes related to remote education during the covid-19 pandemic.

The main objective of this study is to explore the teachers' perspective on the impact of the Covid-19 pandemic on teaching activities, with regard to the mediation 
of flipped classes in order to understand the scenario related to changes in behavior, adaptation and problem solving. in teaching computer science programming.

The results can broaden the understanding of the flipped learning approach and active learning methodologies. The discussion can contribute significantly to the planning and restructuring of the teaching and learning process. This research involves an exploratory, qualitative study, with 52 higher education teachers. The results will be covered in the following topic.

\section{Results}

The results were obtained through a thorough analysis of the questionnaire applied to teachers to investigate the experience related to teaching and learning. The responses were analyzed according to the speech analysis guidelines for qualitative research by Fairclought (2004).

The guidelines for design and implementation of remote education were used during the analysis of the questionnaire (CHOI; TINIO, 2020):

- Guideline 1 (G 1) - Why (Content), related to understanding the reason about the use of learning methodologies.

- Guideline 2 (G 2) - Who (Learning profile, current status and needs), related to understanding the learning profile of students, the current status of the teaching and learning process and adaptations that involve the analysis of students' needs.

- Guideline 3 (G 3) - How (Learning, Design and Implementation), related to how to prepare, plan, implement and favor learning with the use of active learning methodologies.

In this research, three key guidelines (CHOI; TINIO, 2020) were used as categories of analysis, according to the discourse analysis (FAIRCLOUGHt, 2004), 52 responses related to 20 questions were analyzed. Table 1 shows the result related to selected questions proposed in the questionnaire. The result was categorized according to the three guidelines (categories of analysis), in which the first indicates that the teacher understands the reason for using learning methodologies, the second 
that the teacher understands the student's learning profile and the third that the teacher is prepared to prepare and implement active learning methodologies.

All responses were analyzed, table 1 contains the analysis of the answers to the selected questions, based on the three guidelines for the design and implementation of distance education, in which each question was checked according to each guideline and "Yes" was set for answers that are in agreement and "No" for answers that are not in accordance with the guidelines. The selected questions were chosen because they represent the main results obtained.

Table 1 - Selected Questions

\begin{tabular}{|c|c|c|c|c|}
\hline Questions & Responses & G1 & $G 2$ & G3 \\
\hline \multirow{2}{*}{$\begin{array}{l}\text { Do you use any teaching method to promote } \\
\text { student participation in classes? Which one? }\end{array}$} & Yes & 23 & 18 & 21 \\
\hline & No & 29 & 34 & 31 \\
\hline \multirow{2}{*}{$\begin{array}{l}\text { Do you use any technique to help students solve } \\
\text { problems? Which one? }\end{array}$} & Yes & 24 & 19 & 20 \\
\hline & No & 28 & 33 & 32 \\
\hline \multirow{2}{*}{$\begin{array}{l}\text { Do you believe that you could be more productive } \\
\text { for your classes than the content previously studied } \\
\text { at home and that time in class was dedicated to } \\
\text { clarifying doubts, solving and solving problems? }\end{array}$} & Yes & 16 & 19 & 17 \\
\hline & No & 36 & 33 & 35 \\
\hline \multirow{2}{*}{$\begin{array}{l}\text { Do you have knowledge of how students organize } \\
\text { themselves to carry out group work / projects? }\end{array}$} & Yes & 20 & 17 & 18 \\
\hline & No & 32 & 35 & 34 \\
\hline \multirow{2}{*}{$\begin{array}{l}\text { Did you take an online course that you organized at } \\
\text { the school? What instructions have been most } \\
\text { helpful? }\end{array}$} & Yes & 19 & 21 & 20 \\
\hline & No & 33 & 31 & 32 \\
\hline \multirow{2}{*}{$\begin{array}{l}\text { During the pandemic, how have you prepared } \\
\text { activities before online classes? }\end{array}$} & Yes & 19 & 17 & 15 \\
\hline & No & 33 & 35 & 37 \\
\hline \multirow{2}{*}{$\begin{array}{l}\text { If you use pre or post-class activities, how have you } \\
\text { checked if there is procrastination (delay) of the } \\
\text { students in carrying out the activities? }\end{array}$} & Yes & 23 & 20 & 17 \\
\hline & No & 29 & 32 & 35 \\
\hline
\end{tabular}

Fonte: Authors (2021).

Regarding the use of teaching methods to promote student participation in classes, table 1 indicates that 23 teachers adequately understand the reason for using teaching methods and that 23 expressed doubts about the use of teaching methods. It also shows that 18 teachers understand the importance of using teaching methods to contribute to solving the needs of students in remote education during the 
pandemic, 34 demonstrated doubts about understanding the use of teaching methods in relation to the profile of students. About being prepared to develop and implement teaching methods during remote classes, 21 teachers demonstrated to be prepared and 31 teachers demonstrated unpreparedness for the construction of the classes.

When applying the discourse analysis associated with the verification of the three guidelines proposed in the methodology, concerning the use of teaching methods to promote student participation in classes, for example, we can observe that the interviewee, when asked about, uses any teaching method to promote the participation of students in classes and which would be the method, respondents 1 and 4, answered "None", which demonstrates total unpreparedness about the use of teaching methodologies that help to promote student participation. Interviewee 8 answered by "Questionings", which also shows doubt and unpreparedness and the non-compliance with guideline 1, related to understanding the reason about the use of learning methodologies. It would be desirable for professors to know the reason and the importance of using learning methodologies that can contribute to the success of flipped learning during remote teaching. In general, professor's show innumerable doubts, which, if not resolved, could harm teaching and learning.

The results obtained from the analysis of the use of teaching methods to promote student participation in classes indicate that most teachers have difficulties and doubts to prepare the classes and use the available resources in an appropriate way, which can make it difficult for the teacher to mediate during the classes.

In summary with regard to analysis guideline 1, the professors in our samples understand the need to use active learning methodologies, but most still have doubts and / or demonstrate insecurity in the face of methodologies that can promote collaboration and interaction.

Regarding the guideline 2, the professor's show concern in understanding the learning profile of the students, however, they show the doubts about how to identify this profile, when responsible in the remote teaching. There is also some difficulty in verifying the current status of teaching and learning, which makes it difficult to insert adaptations that involve an analysis of the needs of students. Professors also had difficulty in detecting and implementing actions to mitigate student procrastination. 
Analyzing guideline 2 in the use of techniques to help students solve problems, the teacher was asked if any technique is used to help students solve problems and which technique is used, interviewee 1 answered "No", interviewee 3 also answered "No" and interviewee 4 replied "I do not know the name of the technique, which demonstrates that the teacher has difficulty for understanding the students' learning profile, the current status of the teaching and learning process and how to make adaptations that involve the analysis of the students' needs.

The analysis involving guideline 3 , related to how to prepare, plan, implement and favor learning using active learning and collaborative methodologies, reveals that professors have doubts about active and group learning methodologies and are unaware of students' group practices; some know the methodology, but reported using it superficial; some report ignorance about these methodologies and how to apply them to remote education, which can also hinder the preparation and planning of classes.

Regarding guideline 3, when the teachers were asked how the activities that take place before online classes have been prepared, interviewee 1 answered only "Yes", interviewee 3 also answered only "Yes", interviewee 6 answered "No" and respondent 7 answered "Not yet", which shows difficulty in meeting the third guideline, related to how to prepare, plan, implement and favor learning with the use of active methodologies. The results indicate that most professors have significant difficulties in preparing, planning and implementing methodologies that can favor teaching and learning.

The analysis of the results indicated that teachers are unaware of strategies for the use of self-regulation and co-regulation by students. The results show that teachers are not prepared to face challenges related to the use of inverted learning in the context of programming. Teachers demonstrate lack of knowledge about techniques to promote interaction, motivation, collaboration and problem solving. They also have difficulties in promoting strategies to instigate the student to promote reflections on their own learning.

The research obtained relevant results; all participants had to migrate in an emergency way to remote education due to the pandemic by the coronavirus (Covid- 
19). However, countless difficulties are observed, since the implementation of methodologies that can contribute to teaching and learning and the difficulty of using distance learning platforms as a priority.

\section{Discussion}

The purpose of this article was to analyze the challenges of computer programming teachers to facilitate the configuration of the discipline of flipped learning activities during COVID-19. To achieve this objective, a structured questionnaire was prepared (MATHERS; FOX; HUNN, 2009), the responses were analyzed according to the speech analysis model (FAIRCLOUGHT, 2004) and evaluated according to the guidelines for the design and implementation of the remote education (CHOI; TINIO, 2020).

An analysis carried out indicates that the activities in a classroom involves a mutual collaboration between teachers and students. Both have a fundamental role for teachers to be successful in mediating classroom activities, having the opportunity to support and motivate students to engage and monitor their own activities. However, with the immediate shift to remote education, due to the social isolation promoted by COVID-19, there was a necessary change in adapting to this new teaching model, which, if not informed, can lead to a social disconnect, making activities less interactive, which can compromise student learning (MACMAHON; LEGGETT; CARROLL, 2020).

The results of this research showed that many computer programming teachers are unaware of strategies to promote students' self and co-regulation, pointing out the need for future research focusing on teacher training.

To help the teacher overcome the challenges observed during learning related to remote teaching, there is a need for a didactic presentation of well-established strategies, such as collaboration scripts (MACMAHON; LEGGETT; CARROLL, 2020) and prompts (JENKINS, 2009), addressing its contextualization and exemplification, according to the needs of specific content in programming.

The development of research that contextualizes and disseminates generic strategies in programming teaching can significantly contribute to the teaching and 
learning process and can help to overcome the difficulties imposed by the pandemic by Covid-19.

\section{Final Considerations}

The COVID-19 pandemic promoted numerous challenges for education, the immediate migration to remote education brought some discomfort and discomfort to teachers. The use of flipped learning in teaching programming during the pandemic has become even more challenging, as remote teaching has led to doubts and difficulties.

However, the use of active learning methodologies and appropriate teaching strategies can significantly help the teaching and learning processes. There is a demand for research studies and educational politics to disseminate strategies for the teacher to mediate student's self and co-regulation of the activities to be carried out, in order to achieve a better learning.

As future work, we propose the creation and implementation of a specific framework encompassing processes and strategies to foster student's self and coregulation during flipped activities.

\section{References}

AKÇAYIR, G.; AKÇAYIR, M. The flipped classroom: A review of its advantages and challenges. Computers and Education, v. 126, p. 334-345, 2018.

ALHAZBI, S. Using flipped classroom approach to teach computer programming. In: IEEE INTERNATIONAL CONFERENCE ON TEACHING, ASSESSMENT, AND LEARNING FOR ENGINEERING, 2017, Bangkok. Proceedings... [S.l.]: IEEE, 2017. p. 441-444.

ANNAN, K.; ONODIPE, G.; STEPHENSON, A. Using student-created content videos in flipped learning to enhance student higher-order thinking skills, engagement, and satisfaction. Journal of Education and Social Policy, v. 6, n. 3, p. 22-31, set. 2019.

AWIDI, I. T.; PAYNTER, M. The impact of a flipped classroom approach on student learning experience. Computers and Education, v. 128, p. 269-283, 2019.

BAARS, M.; WIJNIA, L. The relation between task-specific motivational profiles and training of self- regulated learning skills. Learning and Individual Differences, v. 64, p. 125-137, 2018. 
BAO, W. Covid-19 and online teaching in higher education: A case study of Peking university. Human Behavior and Emerging Technologies, v. 2, p. 113-115, 2020.

BERGMANN, J.; SAMS, A. Flip Your Classroom: Reach Every Student in Every Class Every Day. Washington, D.C.: International Society for Technology in Education, 2012.

BLAU, I.; SHAMIR-INBAL, T. Digital competences and long-term ICT integration in school culture: The perspective of elementary school leaders. Education and Information Technologies, v. 22, n. 3, p. 769-787, 2017.

BOELENS, R. DE WEVER, B.; VOET, M. Four key challenges to the design of blended learning: A systematic literature review. Educational Research Review, v. 22, p. 1-18, 2017.

CHEN, M. R. A.; HWANG, G.-J.; CHANG, Y.-Y. A reflective thinking-promoting approach to enhancing graduate students' flipped learning engagement, participation behaviors, reflective thinking and project learning outcomes. British Journal of Educational Technology, v. 50, n. 5, p. 2288-2307, set. 2019.

CHOI, A. T.; TINIO, V. Teachers Guide Remote Learning for During School Closures and Beyond. Hong Kong: The Education University of Hong Kong, 2020.

CRESWELL, J. W. A Concise Introduction to Mixed Methods Research. Lincoln: SAGE, 2015.

DOO, M. Y.; BONK, C. J.; SHIN, C. H.; WOO, B. Structural relationships among selfregulation, transactional distance, and learning engagement in a large university class using flipped learning. Asia Pacific Journal of Education, v. 41, n. 3, p. 609-625, 2020.

DURAK, H. Y. Flipped learning readiness in teaching programming in middle schools: Modelling its relation to various variables. Journal of Computer Assisted Learning, v. 58, n. 1, p. 160-199, mar. 2019.

FAIRCLOUGHT, N. Analyzing Discourse: Textual analysis. London: Routledge, 2004.

FIDALGO-BLANCO, A.; MARTÍNEZ-NUÑEZ, M.; BORS-GENE, O.; SANCHEZMEDINA, J. J. Micro flip teaching - an innovative model to promote the active involvement of students. Computers in Human Behavior, v. 72-C, p. 713-723, jul. 2017.

HALVERSON, L. Conceptualizing blended learning engagement. Brigham: Brigham Young University, 2016.

HIRSTO, L.; VAISAANEN, S.; ARFFMAN, A. Exploring students' experiences of selfregulated learning during a large flipped classroom course in teacher education. International Journal of Learning, Teaching and Educational Research, v. 18, n. 13, p. 107-132, dez. 2019.

HUNG, H.-C.; LIU, I.-F.; LIANG, C.-T.; SU, Y.-S. Applying educational data mining to explore students' learning patterns in the flipped learning approach for coding education. Symmetry Journal, v. 12, n. 2, 213, 2020.

JENKINS, O. F. Developing teachers' knowledge of students as learners of mathematics through structured interviews. Journal of Mathematics Teacher Education, v. 13, p. 141-154, 2009. 
KARACA, C.; OCAK, M. A. Effect of flipped learning on cognitive load: A higher education research. Journal of Learning and Teaching in Digital Age, v. 2, n. 1, p. 20-27, 2017.

KHAN, S. H.; ABDOU, B. O. Flipped classroom: How institutions of higher education of Bangladesh could move forward during covid 19 pandemic. SSRN Electronic Journal, v. 4, n. 1, 100187, 2021.

$\mathrm{KOH}, \mathrm{J}$. H. L. Four pedagogical dimensions for understanding flipped classroom practices in higher education: A systematic review. Educational Sciences: Theory and Practice, v. 19, n. 4, p. 14-33, out. 2019.

LA MARCA, A.; LONGO, L. Addressing student motivation, self-regulation, and engagement in flipped classroom to decrease boredom. In International Journal of Information and Education Technology, v. 7, n. 3, p. 230-235, mar. 2017.

LI, C.; LALANI, F. The covid-19 pandemic has changed education forever. This is how. The World Economic Forum, 29 abr. 2020.

LOFTSSON, H.; MATTHÍASDÓTTIR, A. Using flipped classroom and team-based learning in a first- semester programming course: An experience report. In: IEEE INTERNATIONAL CONFERENCE ON ENGINEERING, TECHNOLOGY AND EDUCATION, 2019, [S.l.]. Proceedings... [S.1.]: IEEE, 2019.

MACMAHON, S.; LEGGETT, J.; CARROLL, A. Promoting individual and group regulation through social connection: strategies for remote learning. Information and Learning Sciences, v. 121, n. 5/6, p. 353-363, 2020.

MATHERS, N.; FOX, N.; HUNN, A. Surveys and Questionnaires. Nottingham: The NIHR RDS for the East Mid- lands, 2009.

MAYCOCK, K.; LAMBERT, J.; BANE, D. Flipping learning not just content: A 4-year action research study investigating the appropriate level of flipped learning. Journal of Computer Assisted Learning, v. 34, 2018.

NERANTZI, C. The use of peer instruction and flipped learning to support flexible blended learning during and after the covid-19 pandemic. International Journal of Management and Applied Research, v. 7, n. 2, jun. 2020.

PEETHAMBARAN, M. K. P.; RENUMOL, V. G.; MURTHY, S. Flipped classroom strategy to help underachievers in Java programming. In: INTERNATIONAL CONFERENCE ON LEARNING AND TEACHING IN COMPUTING AND ENGINEERING, 2018, Auckland. Proceedings... [S.l.]: IEEE, 2019.

RASHEED, A. R.; KANSIN, A.; ABDULLAH, N. A; KAKUDI, H. Self-regulated learning in flipped classrooms: A systematic literature review. International Journal of Information and Education Technology, v. 10, n. 11, p. 848-853, 2020.

SHIH, H.-C. J.; SHENG-HUI, C. H. EFL learners' metacognitive development in flipped learning: a comparative study. Interactive Learning Environments, v. 28, p. 1-13, 2020. 
VOJINOVIC, O.; SIMIC, V.; MILENTIJEVIC, I.; CIRIC, V. Tiered assignments in lab programming sessions: Exploring objective effects on students' motivation and performance. IEEE Transactions on Education, v. 63, n. 3, p. 164-172, 2020.

YAMASHITA, K.; YASUEDA, H. Project-based learning in out-of-class activities: flipped learning based on communities created in real and virtual spaces based on communities created in real and virtual spaces. Procedia Computer Science, v. 112, p. 1044-1053, 2017.

ZAINUDDIN, Z.; HARUNA H.; LI, X. L.; ZHANG, Y; CHU, S. K. W. A systematic review of flipped classroom empirical evidence from different fields: what are the gaps and future trends? On the Horizon, v. 27, n. 2, p. 72-86, 2019.

ZHENG, X.-L.; KIM, H.-S.; LAI, W.-H.; HWANG, G. Cognitive regulations in ICTsupported flipped class- room interactions: An activity theory perspective. British Journal of Educational Technology, v. 51, n. 1, p. 103-130, mar. 2019.

RECEBIDO: 08/06/2021

APROVADO: $14 / 10 / 2021$

RECEIVED: 06/08/2021

APPROVED: $10 / 14 / 2021$

RECIBIDO: 08/06/2021

APROBADO: $14 / 10 / 2021$ 